
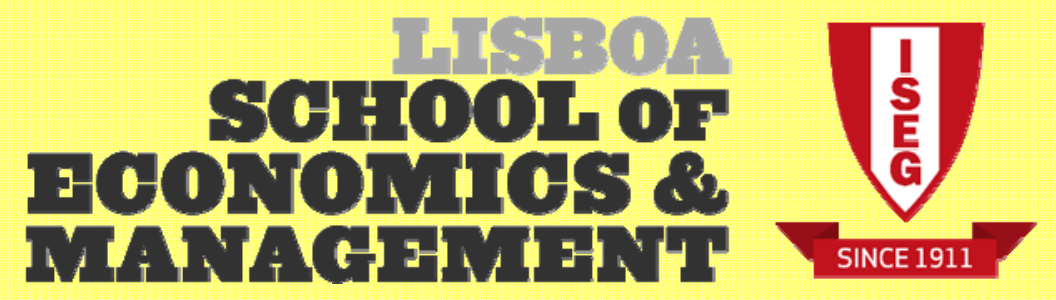

Department of Economics

António Afonso \& Maria João Guedes

\title{
EU Finance Ministers, Capital Markets and Fiscal Outcomes
}




\title{
EU Finance Ministers, Capital Markets and Fiscal Outcomes
}

\author{
António Afonso \$, Maria João Guedes \#
}

December 2013

\begin{abstract}
We investigate the relevance of the characteristics of Ministers of Finance as an influence on the development of stock returns, sovereign yields and fiscal outcomes, which result from the implementation of their fiscal policies. For a panel of $27 \mathrm{EU}$ countries, covering the period of 1980-2012, we find that academic background, tenure and gender, play a role in determining stock and bond market returns, as well as the general fiscal position of governments.
\end{abstract}

JEL: G10, G12, H30, H62.

Keywords: finance minister, stock returns, sovereign yields, budget balance.

\footnotetext{
* We thank Luís Teles de Morais for his excellent research assistance. The opinions expressed herein are those of the authors and do not necessarily reflect those of the ECB or the Eurosystem.

\$ ISEG/ULisbon - University of Lisbon, Department of Economics; UECE - Research Unit on Complexity and Economics, R. Miguel Lupi 20, 1249-078 Lisbon, Portugal, email: aafonso@iseg.utl.pt. UECE is supported by the Fundacão para a Ciência e a Tecnologia (Portuguese Foundation for Science and Technology) through the PEst-OE/EGE/UI0436/2011 project. European Central Bank, Directorate General Economics, Kaiserstraße 29, D-60311 Frankfurt am Main, Germany..

\# ISEG/ULisbon - University of Lisbon,, Department of Management; ADVANCE - Centro de Investigação Avançada em Gestão do ISEG, R. Miguel Lupi 20, 1249-078 Lisbon, Portugal. email: mjguedes@iseg.utl.pt. Advance is supported by the FCT (Fundação para a Ciência e a Tecnologia, Portugal).
} 


\section{Introduction}

The 2010-2012 European Union (EU) debt crisis, which followed the 2008-2009 economic and financial crisis, is an important constraint for the implementation of economic policy, notably in the EU. Alongside such constraints, one also needs to take into account the characteristics of policy makers, notably their background, to understand to what extent they play a role in steering policy and in taking the most adequate decisions.

Economic, institutional and supra-individual features are usually the relevant determinants of capital markets and fiscal outcomes. Governments are responsible for the implementation of economic policy, notably at macro level, and therefore the behaviour of governments may play a role as a potential determinant of both capital markets and fiscal outcomes. Moreover, as Ministers of Finance are major key players in the implementation of fiscal and macroeconomic policies, their personal characteristics are quite relevant to this question, especially with regard to their academic and professional background.

So far, the literature has focussed on the role of political parties and, in particularly, the Head of the Party and their choices (Jones and Olken, 2005). However, little has been written about the role of those who are responsible for financial issues. Finance Ministers play an important role in determining public deficit (Jochimsen and Thomasius, 2012), public debt (Moessinger, 2013) and the setting of fiscal agendas (von Hagen et al., 2001). In fact, one question remains under-researched, which is how to assess whether the individual characteristics of Finance Ministers has an effect on the development of capital markets and fiscal variables.

Some of the literature advocates that individuals do play an important role in acting as policy makers. Hence, individual characteristics such as age, gender and political ideology, among others, shape their choices and may influence decisions made in relation to capital markets and fiscal results, such as debt-to-GDP ratio, or even long-term government bond yields.

We add to the literature by assessing the relevance of the characteristics of Ministers of Finance in determining the above-mentioned outcomes, for a panel of EU countries, covering the period of 1980-2012. After controlling for several relevant economic variables, our results show that academic background, tenure and gender, play a role in determining stock and bond market returns, as well as fiscal position. 
The paper is organised as follows: Section 2 reviews the related literature; Section 3 explains the setting up of the dataset; Section 4 reports the empirical analysis and Section 5 concludes.

\section{Related literature}

The personal characteristics of Finance Ministers

The literature examines the factors that influence budget deficits or government debt by considering several aspects. On one hand, fiscal outcomes are associated with procedural rights (Hagen and Harden, 1995; Hallerberg and Nuscheler, 2011), and the relationship between fiscal outcomes and Finance Ministers is examined (Jochimsen and Nuscheler, 2011). On the other hand, other studies assess the influence of the number of parties or ministers in a government (Haan et al., 1999, Volkerink and de Haan, 2001 and Perotti and Kontopoulos, 2002), as well as the amount of time a government remains in office (Haan et al., 1999). These latter studies also analyse ideological affiliation and the degree of ideological polarisation (Volkerink and de Haan, 2001), plus behaviour experienced prior to elections (Brender and Drazen, 2005).

However, the literature has neglected the role of Finance Ministers and centres attention on Heads of Government (e.g. Dreher et al., 2009; Somogyi, 2010, and Congleton and Zhang, 2009 for US Presidents), or institutions (Hambrick and Mason, 1984; Hambrick, 2007). In addition, business/management literature has focussed more on the relationship between CEOs' personal characteristics, as they act as the leader and decision maker, as well as the performance of companies (e.g. Adams and Ferreira, 2009; Nelson, 2005; Bhagat, Boltom and Subramanian, 2010). Moreover, very little literature is available that explores the personal characteristics of Finance Ministers and their relationship to performance and fiscal outcomes.

\section{Gender}

Gender has been pointed out as being one of the important characteristic in terms of attitudes towards spending. The literature explains that women and men do not show the same attitude towards spending, with women usually preferring greater public spending (Edlund and Pande, 2002, Baltrunaite, et al., 2012). In particular, women seem to give priority to spending public money on welfare (e.g. Bertocchi, 2011; Rehavi, 2007), for example, Svaleryd (2009) finds a positive relationship between the presence of women and government spending in 
areas such as childcare, education and care for the elderly. In another context, Muravyev et al. (2013) report that female-managed firms are less likely to obtain a bank loan.

Furthermore, there is also some evidence that women channel more public funds to projects related to women's needs. For example, Chattopadhyay and Duflo (2004) show that women leaders spend more on the needs of rural Indian women, such as water and road projects, whilst Clots-Figueras (2011) report evidence that Indian woman leaders invest more in health and early education. There is also evidence pointing to a higher reduction of inflation when women are present in government (Farvaque, Hammadou and Stanek, 2009, 2011). In a study that covers Ministers of Finance in former West Germany over the period of 1960-2009, Jochimsen and Thomasius (2012) found that the gender of the Minister of Finance does not play any role in influencing the outcome of budget deficits.

Age

Age is a personal characteristic that is likely to affect work attitudes and behaviour (Taylor, 1975; Rhodes, 1983). In the particular case of the chronologically ordered age of Finance Ministers, there is little empirical evidence that it affects the performance of budget deficits. The notable exceptions are the studies of Besley and Case (1995), and Jochimsen and Thomasius (2012). The results of the former study show that Finance Ministers approaching retirement age tend to be associated with greater budget deficits. However, the latter study does not confirm this finding and shows that age has no influence on budget deficits.

\section{Academic background}

Another documented personal characteristic that contributes to deficit policy is academic background. Besley, Montalvo and Reynal-Querol (2011) advocate that more educated leaders have more ability to act in the public interests. However, they fail to demonstrate the impact of higher education on performance. Political leaders with an economic or legal background are linked to higher budget deficits (Mikosch and Somogyi, 2009). However, once more, the specific link between the education background of Finance Ministers and fiscal outcomes has yet to be explored. A noteworthy exception is Jochimsen and Thomasius (2012) and Moessinger (2013), who show that education does not seem to have an influence when it comes to budget deficits. However, the same authors argue that the prior experience of Finance Ministers is more likely to affect budget deficits. Moessinger (2013) mentions that Finance Ministers with a previous background in politics are associated with lower 
government debt and are alleged to be responsible for greater fiscal discipline and that leftwing governments are less fiscally disciplined when they are led by former students of Economics.

\section{Tenure}

The literature also addresses the relevance of the length of years in the position of Finance Ministers in relation to public spending preferences. The evidence suggests that Finance Ministers with more time in the position tend to exhibit more stability and discipline and, hence, they are associated with lower deficits (Feld and Schaltegger, 2012; Jochimsen and Thomasius, 2012; Moessinger, 2013).

\section{Political characteristics}

The political ideology of political leaders, with Finance Ministers in particular, may have an impact on fiscal policies. However, the literature is not consensual. Some authors favour the argument that left-wing ideologies are usually concerned with the redistribution of wealth and welfare, and are thus associated with greater spending and higher deficits. Golden and Poterba (1980) supported this argument empirically for the US, as well as Roubini and Sachs (1989) for the OECD, and Baskaran (2012) for Germany; all of whom report results showing that left-wingers are bigger spenders when compared to right-wing and mixed-ideology governments. However, other authors claim that ideology has no impact on the development of public finance (e.g. de Haan and Sturm, 1994, 1997; Tavares, 2004 and Moessinger, 2013).

\section{Data and stylized facts}

In Table 1 we report some descriptive statistics regarding the data set that we compiled. We use an unbalanced panel data for the period 1980-2012, covering $27 \mathrm{EU}$ countries: Austria, Belgium, Bulgaria, Cyprus, the Czech Republic, Denmark, Estonia, Finland, France, Germany, Greece, Hungary, Ireland, Italy, Latvia, Lithuania, Luxembourg, Malta, the Netherlands, Poland, Portugal, Romania, Slovakia, Slovenia, Spain, Sweden, and the United Kingdom.

As one can see from Table 1, both left and right wing parties have a similar presence in all countries throughout the period, and they are the dominant choices of party. 
Overall, the average age of Finance Ministers was nearly 51 years old and they do not tend to stay long in that position, the average tenure being about 2 years. Overall, we can see that during that period, only $4 \%$ of Finance Ministers were women.

[Table 1]

For our data set we collected information regarding the academic background of Finance Ministers (or Ministers of Economics, depending on who is in charge of fiscal policy in each country) for the 27 countries throughout the period. We coded the academic background of ministers as follows: Economics, Law, Management, Finance/Accounting, Other Social Sciences, "Hard sciences" and "No formal Tertiary Education". We then coded the respective categories as dummy variables for the purpose of formal estimation. As one can see from Table 2, the most frequent background for Ministers of Finance is Economics (41.2\%), Law (21.8\%), and Finance/Accounting (10.1\%).

[Table 2]

\section{Empirical analysis}

The baseline specification for the return in the capital markets, $R$, is given by:

$$
R_{i t}=c_{i}+\lambda R_{i t-1}+\omega_{1} y_{i t-1}+\omega_{2} \Delta d e b t_{i t}+\omega_{3} U_{i t}+\omega_{4} \pi_{i t}+\delta_{1} X_{i t}
$$

where the index $i$ denotes the country, the index $t$ indicates the period, $c_{i}$ stands for the individual effects to be estimated for each country $i$. In addition we consider: $y-10$-year sovereign bond yield; debt - debt ratio; $U$ - unemployment rate; $\pi$ - inflation rate; $X-$ includes a set of variables describing several characteristics of Minister of Finances (for instance, female or male, age, tenure, area of academic degree).

Regarding the baseline specification for the 10-year sovereign yield, $y$, we used:

$$
y_{i t}=c_{i}+\lambda y_{i t-1}+\omega_{1} R_{i t-1}+\omega_{2} \Delta d e b t_{i t}+\omega_{3} U_{i t}+\omega_{4} \pi_{i t}+\delta_{1} X_{i t}+\delta_{1} Z_{i t}
$$

where $Z$ includes a set of variables describing several aspects related to political developments (for instance: left or right wing government affiliation, majority governments, number of seats 
in Parliament). In addition, in (2), the change in debt ratio also alternates with the budget balance ratio, in order to complement the assessment of the impact of fiscal stance on longterm sovereign bond yields.

Finally, in the third baseline, we directly check for the determinants of fiscal stance, which is measured by budget balance, as fiscal policy is mainly under the control of the Minister of Finance:

$$
\text { budbal }_{i t}=c_{i}+\lambda y_{i t-1}+\omega_{1} R_{i t-1}+\omega_{2} \operatorname{debt}_{i t-1}+\omega_{3} U_{i t}+\omega_{4} \pi_{i t}+\delta_{1} X_{i t}+\delta_{1} Z_{i t}
$$

\subsection{Capital markets outcomes}

The estimation results for specification (1) regarding yearly stock market returns are reported in Table 3. Accordingly, we can see that higher levels of sovereign debt and inflation have a positive effect on stock market returns, whilst an increase in the rate of unemployment reduces those market returns. Regarding the various characteristics of Ministers of Finance, we can find that if they have a degree ("Degree 5" dummy) in "Other Social Sciences" (but not in Economics, Law, Management, Finance, or Accounting), this has a positive effect on stock market returns in our panel analysis. Nevertheless, with robust standard errors, these results are less significant.

\section{[Table 3]}

In terms of the results of 10-year sovereign bond yields (specification (2)), in Table 4, we can observe upward effects resulting from the change in debt ratio and inflation. In addition, the pressure of unemployment on sovereign bond yields may stem from the fact that a higher fiscal spending in unemployment benefits implies an additional need for governments to raise financing in capital markets. This, therefore, necessarily implies higher budget deficits, which is a similar conclusion to that of the positive effect of higher debt ratios on yields. Interestingly, stock returns also have a positively impact on bond returns, whilst the reverse effect was not present in the specification for stock market returns in Table 2 above.

Regarding the characteristics of Ministers of Finance, we see that if the minister is a woman, then this has a statistical significant effect on the reduction of 10-year sovereign yields, which is a result that holds true in nearly all specifications. On the other hand, we find 
one case where if the Minister of Finance has a background in Management (dummy coded as "Degree 3"), this increase 10-year sovereign bond yield.

[Table 4]

\subsection{Fiscal outcomes}

Table 5 reports the estimation results for specification (3), regarding the possible determinants of budget balance. Interestingly, we uncover a Ricardian behaviour in the panel, given that budget balance improves when there is an increase in the debt ratio of the previous period. Again, the effect of unemployment shows up in statistical terms, with higher unemployment rates translating into a worsening of the fiscal position,

The fact that the Minister of Finance is a woman plays a statistically significant role again, but in this case, by worsening the fiscal position. On the other hand, tenure improves budget balance, with an improvement of budget balance by around $0.14 \mathrm{pp}$ of GDP for each year that the Finance Minister was in charge.

Additionally, when considered separately from tenure, academic background of Finance Ministers also plays a role. Indeed, having no formal education or possessing an academic background in Economics, Law or Finance/Accounting (respectively Degree 0, 1, 2, and 4), contributes to an improvement in budget balance position in a statistically significant fashion.

\section{[Table 5]}

\section{Conclusion}

We investigate the relevance of the characteristics of Ministers of Finance as an influence on the development of capital markets, stock returns, yields and fiscal outcomes for a panel of 27 EU countries, covering the period of 1980-2012.

The results of our empirical analysis can be summarised as follows: a degree in "Other Social Sciences" (not Economics, Law, Management, Finance, or Accounting) has a positive effect on stock market returns. A background in Management increases 10-year sovereign bond yield. Having no formal education or possessing an academic background in Economics, Law or Finance/Accounting, improves the budget balance position. 
In addition, if the Minister is woman, this has a statistical significant effect in reducing 10-year sovereign yield, but it also worsens the fiscal position. Moreover, the number of years Finance Ministers have consecutively been in charge improves budget balance.

\section{References}

Adams, R and Ferreira, D. (2009), "Women in the boardroom and their impact on governance and performance", Journal of Financial Economics, 94 (2), 291-309.

Baskaran, T. (2012). "Ideology and fiscal policy: quasi-experimental evidence from the German States". University of Goettingen. Department of Economics, Center for European, Governance and Economic Development Research Discussion Paper 144.

Bhagat, S,, Bolton, B.., Subramanian, A., (2010). "CEO Education, CEO Turnover, and Firm Performance", mimeo.

Baltrunaite, A., Bello, P., Casarico, A., Profeta, P. (2012). "Gender quotas and the quality of politicians", CESifo Working Paper 3734.

Bertocchi, G. (2011). "The Enfranchisement of Women and the Welfare State", European Economic Review, 55(4), 535-553.

Besley, T., Montalvo, J. , Reynal-Querol, M. (2011). "Do Educated Leaders Matter? Economic Journal, 121(554), F205-227.

Chattopadhyay, R., Duflo, E. (2004). "Women as policy-makers: Evidence from a randomized policy experiment in India", Econometrica, 72(5), 1409-1443.

Clots-Figueras, I. (2011). "Women in politics: Evidence from the Indian States", Journal of Public Economics, 95(7-8), 664-690.

De Haan, J., Sturm, J. (1997). "Political and economic determinants of OECD budget deficits and government expenditures: A reinvestigation", European Journal of Political Economy, 13(4), 739-750.

De Haan, J., Sturm, J. (1994). "Political and institutional determinants of fiscal policy in the European Community", Public Choice, 80 (1-2), 157-172.

Dreher, A, Lamla, M.., Lein, S., Somogyi, F. (2009). "The impact of political leaders' profession and education on reforms," Journal of Comparative Economics, 37(1), 169193. 
Edlund, L. and Pande, R. (2002). "Gender politics: The political salience of marriage”, Discussion Papers 0102-56, Columbia University, Department of Economics.

Farvaque, E., Hammadou, H., Stanek, P. (2009). "Select your committee: The impact of central bankers background on inflation", Economie Internationale 117 (1), 99-129.

Farvaque, E., Hammadou, H., Stanek, P. (2011). "Selecting Your Inflation Targeters: Background and Performance of Monetary Policy Committee Members", German Economic Review 12 (2), 223-238.

Feld, L. , Schaltegger, C. (2010). "Political stability and fiscal policy: time series evidence for the Swiss federal level since 1849", Public Choice,144(3-4), 505-534.

Golden, D., Poterba, J. (1980). "The price of popularity: the political business cycle reexamined", American Journal of Political Science 24, 696-714.

Hambrick, D. , \& Mason, P. (1984). "Upper echelons: The organization as a reflection of its top managers", Academy of management review, 9(2), 193-206.

Hambrick, D. (2007). "Upper echelons theory: An update", Academy of management review, 32(2), 334-343.

Jochimsen, B., Thomasius, S. (2012). "The Perfect Finance Minister: Whom to appoint as Finance Minister to balance the budget?” DIW Discussion Paper 11-88.

Mikosch, H., Somogyi, F. S. (2009). "Individuals vs. institutions. The impact of political leaders' education and profession on public deficits", ETH Zurich, mimeo.

Moessinger M.-D. (2012). "Do Personal Characteristics of Finance Ministers affect the development of Public Debt?” ZEW, Discussion Paper No. 12-068.

Muravyev, A., Talavera, O., Schäfer, D. (2013). "Entrepreneurs' gender and financial constraints: Evidence from international data", Journal of Comparative Economics, 37 (2), 270-286.

Nelson, J. (2005). Corporate governance practices, CEO characteristics and firm performance. Journal of Corporate Finance, 11(1-2), 197-228.

Rehavi, M. (2007). "Sex and politics: Do female legislators affect state spending?", mimeo, Berkeley.

Rhodes, S. (1983). "Age-related differences in work attitudes and behavior: A review and conceptual analysis", Psychological bulletin, 93(2), 328. 
Roubini, N., Sachs, J., 1989. "Political and economic determinants of budget deficits in industrial democracies", European Economic Review 33 (5), 903-933.

Svaleryd, H. (2009). "Women's representation and public spending." European Journal of Political Economy, 25 (2), 186-198.

Tavares, J. (2004). "Does right or left matter? Cabinets, credibility and fiscal adjustments", Journal of Public Economics, 88(12), 2447-2468.

Taylor, R. (1975). “Age and experience as determinants of managerial information processing and decision making performance", Academy of Management Journal, 18(1), 74-81.

von Hagen, J. ( 2002). "Fiscal Rules, Fiscal Institutions, and Fiscal Performance”, Economic and Social Review, 33(3), 263-284. 


\section{Appendix}

Table A1 - Data descritpion and sources

\begin{tabular}{|c|c|c|}
\hline Variable & Description & Source \\
\hline \multicolumn{3}{|c|}{ General Data } \\
\hline Inf & Inflation rate & IMF/WEO \\
\hline Bbal & $\begin{array}{l}\text { General government budget balance, as a percentage of } \\
\text { GDP }\end{array}$ & AMECO [and IMF/WEO] \\
\hline Capb & $\begin{array}{l}\text { Cyclically adjusted primary balance, as a percentage of } \\
\text { GDP }\end{array}$ & AMECO \\
\hline Debt & Government debt stock, as a percentage of GDP & AMECO \\
\hline Unemp & Unemployment rate & AMECO \\
\hline Yield & Benchmark government bond yield & Datastream [and AMECO] \\
\hline Stock & Yearly rate of change of main national stock indices & Datastream and Eurostat \\
\hline Left & $\begin{array}{l}\text { Political positioning of the largest party in government } \\
\text { is Left-wing }\end{array}$ & World Bank/DPI \\
\hline Right & $\begin{array}{l}\text { Political positioning of the largest party in government } \\
\text { is Right-wing }\end{array}$ & World Bank/DPI \\
\hline Center & $\begin{array}{l}\text { Political positioning of the largest party in government } \\
\text { is Centre-wing }\end{array}$ & World Bank/DPI \\
\hline Other & $\begin{array}{l}\text { Political positioning of the largest party in government } \\
\text { is Other, or Not Defined. }\end{array}$ & World Bank/DPI \\
\hline \multicolumn{3}{|c|}{ Finance Ministers' Data } \\
\hline Female & $\begin{array}{l}\text { Dummy variable, equal to } 1 \text { in years where the Finance } \\
\text { Ministers is a woman, } 0 \text { otherwise }\end{array}$ & Own \\
\hline Age & Age of Finance Minister & Own \\
\hline Tenure & $\begin{array}{l}\text { The number of years a Finance Minister has been } \\
\text { consecutively in charge }\end{array}$ & Own \\
\hline Degree1 & Economics & \\
\hline Degree2 & Law & Own \\
\hline Degree3 & Management & Own \\
\hline Degree 4 & Finance/Accounting & Own \\
\hline Degree 5 & Other Social Sciences & Own \\
\hline Degree 6 & Hard Science & Own \\
\hline Degree 0 & No formal education & Own \\
\hline
\end{tabular}


Table 1 - Data set

\begin{tabular}{lccccc}
\hline \multicolumn{1}{c}{ Variable } & $\mathrm{N}$ & Mean & Std. Dev. & Min. & Max. \\
\hline Inf & 734 & 7.76 & 21.76 & -21.48 & 295.48 \\
Bbal & 679 & -3.32 & 4.18 & -30.94 & 9.68 \\
Capb & 676 & 0.39 & 3.38 & -25.48 & 10.43 \\
Debt & 709 & 53.34 & 29.92 & 3.69 & 170.55 \\
Unemp & 732 & 8.27 & 4.14 & 0 & 25.00 \\
Yield & 635 & 7.43 & 3.98 & 1.40 & 27.74 \\
Stock & 593 & 1.94 & 15.93 & -0.99 & 180.49 \\
\hline Left & 891 & 0.38 & 0.49 & 0 & 1 \\
Right & 891 & 0.35 & 0.48 & 0 & 1 \\
Center & 891 & 0.14 & 0.35 & 0 & 1 \\
Other & 891 & 0.09 & 0.28 & 0 & 1 \\
\hline Female & 833 & 0.04 & 0.19 & 0 & 1 \\
Age & 833 & 50.52 & 8.36 & 30 & 93 \\
Tenure & 830 & 2.31 & 2.60 & 0 & 20 \\
\hline Degree 0 & 834 & 0.09 & 0.28 & 0 & 1 \\
Degree1 & 834 & 0.40 & 0.49 & 0 & 1 \\
Degree2 & 834 & 0.21 & 0.41 & 0 & 1 \\
Degree3 & 834 & 0.07 & 0.25 & 0 & 1 \\
Degree 4 & 834 & 0.10 & 0.31 & 0 & 1 \\
Degree 5 & 834 & 0.08 & 0.27 & 0 & 1 \\
Degree 6 & 834 & 0.05 & 0.21 & 0 & 1 \\
\hline
\end{tabular}

Table 2 - Finance Ministers' Academic Background

\begin{tabular}{|l|r|r|r|}
\hline Academic degree & \multicolumn{1}{|c|}{$\#$} & \multicolumn{1}{c|}{$\begin{array}{c}\text { Dummy } \\
\text { code }\end{array}$} & \multicolumn{1}{c|}{$\begin{array}{c}\text { Share } \\
(\%)\end{array}$} \\
\hline Economics & 336 & 1 & 41.2 \\
\hline Law & 178 & 2 & 28.1 \\
\hline Management & 58 & 3 & 7.1 \\
\hline Finance/Accounting & 87 & 4 & 10.7 \\
\hline Other Social Sciences & 66 & 5 & 8.1 \\
\hline "Hard Sciences" & 38 & 6 & 4.7 \\
\hline No formal education & 53 & 0 & 6.5 \\
\hline Total & 816 & & 100 \\
\hline
\end{tabular}


Table 3 - Results for Stock Returns

\begin{tabular}{|c|c|c|c|c|c|c|c|c|}
\hline Dependent & \multicolumn{8}{|c|}{ Stock } \\
\hline Spec. & 1 & 2 & 3 & 4 & 5 & 6 & 7 & 8 \\
\hline Constant & $\begin{array}{l}-9.728 \\
(-0.50) \\
\end{array}$ & $\begin{array}{l}-9.726 \\
(-0.50) \\
\end{array}$ & $\begin{array}{l}12.378 \\
(0.36)\end{array}$ & $\begin{array}{c}-23.192 \\
(-0.86) \\
\end{array}$ & $\begin{array}{l}-9.728 \\
(-0.75) \\
\end{array}$ & $\begin{array}{c}-9.726 \\
(-0.75) \\
\end{array}$ & $\begin{array}{c}12.378 \\
(0.56)\end{array}$ & $\begin{array}{c}-23.192 \\
(-0.84)\end{array}$ \\
\hline L. Stock & $\begin{array}{c}-0.099 * * \\
(-2.51)\end{array}$ & $\begin{array}{c}-0.099 * * \\
(-2.51)\end{array}$ & $\begin{array}{c}-0.099 * * \\
(-2.50)\end{array}$ & $\begin{array}{c}-0.117 * * * * \\
(-2.96)\end{array}$ & $\begin{array}{c}-0.099 * * * \\
(-8.72)\end{array}$ & $\begin{array}{c}-0.099 * * * \\
(-8.69)\end{array}$ & $\begin{array}{c}-0.099 * * * \\
(-8.76)\end{array}$ & $\begin{array}{c}-0.117 \text { **** } \\
(-5.80)\end{array}$ \\
\hline L. Debt & $\begin{array}{c}0.616^{* * *} \\
(2.12)\end{array}$ & $\begin{array}{c}0.615^{* *} \\
(2.12)\end{array}$ & $\begin{array}{c}0.582 * * \\
(1.98)\end{array}$ & $\begin{array}{l}0.522^{*} \\
(1.79)\end{array}$ & $\begin{array}{l}0.616 \\
(1.24)\end{array}$ & $\begin{array}{l}0.615 \\
(1.24)\end{array}$ & $\begin{array}{l}0.582 \\
(1.21)\end{array}$ & $\begin{array}{l}0.522 \\
(1.24)\end{array}$ \\
\hline L. Yield & $\begin{array}{l}-0.858 \\
(-0.67) \\
\end{array}$ & $\begin{array}{l}-0.839 \\
(-0.65) \\
\end{array}$ & $\begin{array}{l}-1.009 \\
(-0.77) \\
\end{array}$ & $\begin{array}{l}-0.727 \\
(-0.56) \\
\end{array}$ & $\begin{array}{l}-0.858 \\
(-0.56) \\
\end{array}$ & $\begin{array}{l}-0.839 \\
(-0.55) \\
\end{array}$ & $\begin{array}{l}-1.009 \\
(-0.62) \\
\end{array}$ & $\begin{array}{l}-0.727 \\
(-0.59) \\
\end{array}$ \\
\hline Unemployment & $\begin{array}{c}-3.030^{*} \\
(-1.91)\end{array}$ & $\begin{array}{c}-3.048^{*} \\
(-1.91)\end{array}$ & $\begin{array}{c}-2.974 * \\
(-1.86)\end{array}$ & $\begin{array}{l}-2.527 \\
(-1.59)\end{array}$ & $\begin{array}{l}-3.030 \\
(-1.19)\end{array}$ & $\begin{array}{l}-3.048 \\
(-1.19)\end{array}$ & $\begin{array}{l}-2.974 \\
(-1.21)\end{array}$ & $\begin{array}{l}-2.527 \\
(-1.16)\end{array}$ \\
\hline Inflation & $\begin{array}{c}3.727 * * \\
(2.19)\end{array}$ & $\begin{array}{c}3.721 * * \\
(2.18)\end{array}$ & $\begin{array}{c}3.657 * * \\
(2.14)\end{array}$ & $\begin{array}{c}3.463 * * \\
(2.03)\end{array}$ & $\begin{array}{l}3.727 \\
(1.00)\end{array}$ & $\begin{array}{l}3.721 \\
(1.00)\end{array}$ & $\begin{array}{l}3.657 \\
(0.99)\end{array}$ & $\begin{array}{l}3.463 \\
(1.02)\end{array}$ \\
\hline \multicolumn{9}{|c|}{ Finance Ministers' characteristics } \\
\hline Female & & $\begin{array}{l}2.053 \\
(0.13)\end{array}$ & $\begin{array}{l}1.228 \\
(0.08)\end{array}$ & $\begin{array}{l}3.361 \\
(0.21)\end{array}$ & & $\begin{array}{l}2.053 \\
(0.37)\end{array}$ & $\begin{array}{l}1.228 \\
(0.23)\end{array}$ & $\begin{array}{l}3.361 \\
(0.44)\end{array}$ \\
\hline Age & & & $\begin{array}{l}-0.336 \\
(-0.64)\end{array}$ & & & & $\begin{array}{l}-0.336 \\
(-0.76)\end{array}$ & \\
\hline Tenure & & & $\begin{array}{l}-1.009 \\
(-0.68)\end{array}$ & & & & $\begin{array}{l}-1.009 \\
(-1.39)\end{array}$ & \\
\hline Degree 0 & & & & $\begin{array}{l}27.153 \\
(1.07)\end{array}$ & & & & $\begin{array}{c}27.153 \\
(1.27)\end{array}$ \\
\hline Degree 1 & & & & $\begin{array}{r}7.554 \\
(0.39)\end{array}$ & & & & $\begin{array}{l}7.554 \\
(0.63)\end{array}$ \\
\hline Degree 2 & & & & $\begin{array}{c}14.008 \\
(0.68)\end{array}$ & & & & $\begin{array}{l}14.008 \\
(0.86)\end{array}$ \\
\hline Degree 3 & & & & $\begin{array}{l}-5.656 \\
(-0.25)\end{array}$ & & & & $\begin{array}{l}-5.656 \\
(-0.33)\end{array}$ \\
\hline Degree 4 & & & & $\begin{array}{l}34.717 \\
(1.48)\end{array}$ & & & & $\begin{array}{l}34.717 \\
(1.61)\end{array}$ \\
\hline Degree 5 & & & & $\begin{array}{c}47.586^{* *} \\
(2.12)\end{array}$ & & & & $\begin{array}{c}47.586 \\
(1.01)\end{array}$ \\
\hline
\end{tabular}

Note: In Column 1 to 4, the models are estimated by Within Fixed Effects (FE). In Column 5 to 8, the models are estimated by Within Fixed Effects (FE) with robust errors.

$\mathrm{t}$ values are reported in parenthesis below each coefficient estimate. $*$, **, *** denote significance at 10,5 and $1 \%$ levels. 
Table 4 - Results for 10-year Sovereign Yields

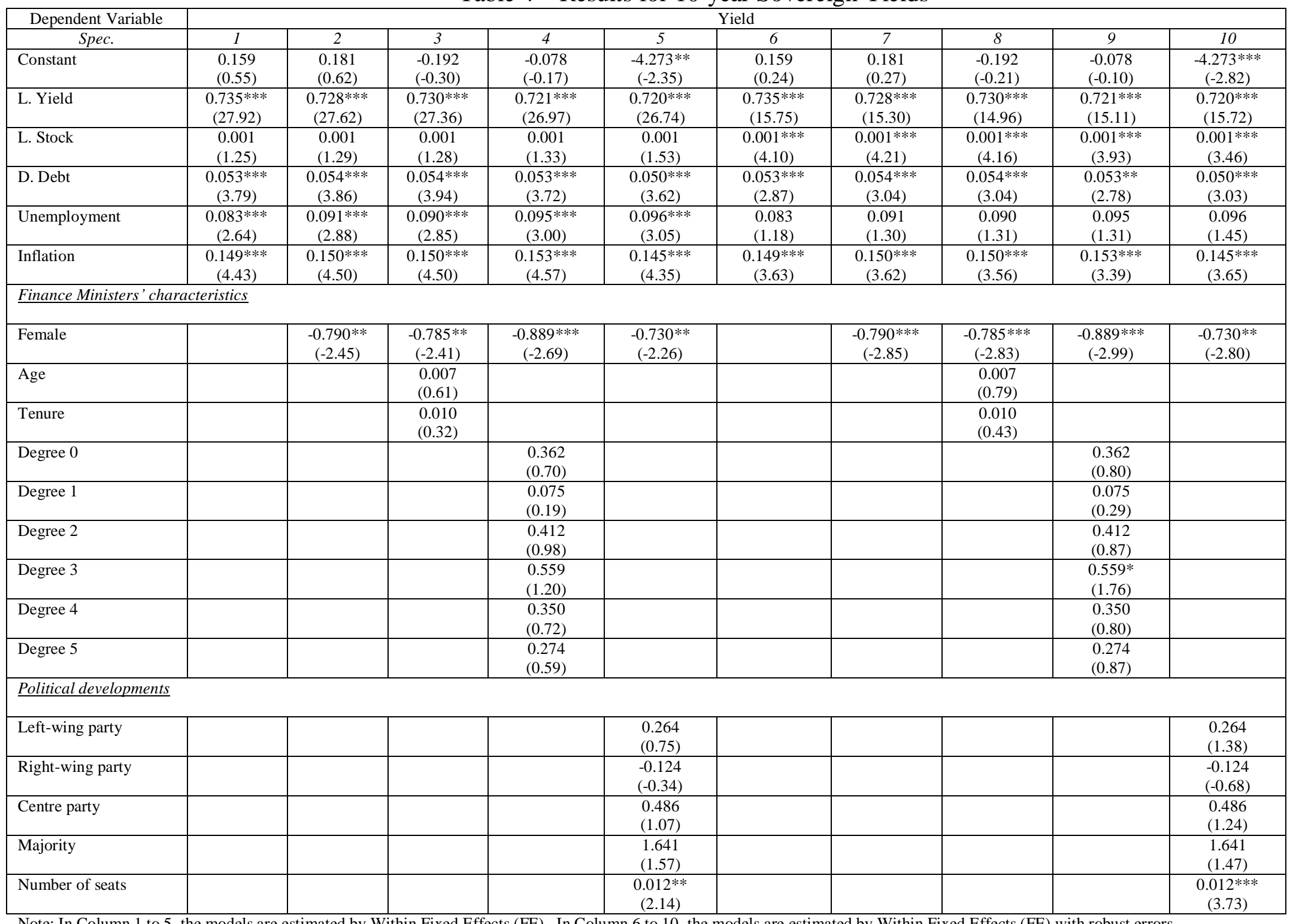

Note: In Column 1 to 5, the models are estimated by Within Fixed Effects (FE). In Column 6 to 10, the models are estimated by Within Fixed Effects (FE) with robust errors

$\mathrm{t}$ values are reported in parenthesis below each coefficient estimate. *,**,** denote significance at 10,5 and $1 \%$ levels. 
Table 5 - Results for Budget Balance

\begin{tabular}{|c|c|c|c|c|c|c|c|c|c|c|}
\hline Dependent Variable & \multicolumn{10}{|c|}{ BBal } \\
\hline Spec. & 1 & 2 & 3 & 4 & 5 & 6 & 7 & 8 & 9 & 10 \\
\hline Constant & $\begin{array}{l}-0.236 \\
(-0.43)\end{array}$ & $\begin{array}{l}-0.365 \\
(-0.67)\end{array}$ & $\begin{array}{c}0.853 \\
(-0.83)\end{array}$ & $\begin{array}{c}-2.286^{* * *} \\
(-2.24)\end{array}$ & $\begin{array}{c}12.390 * * * \\
(4.26)\end{array}$ & $\begin{array}{l}-0.236 \\
(-0.17)\end{array}$ & $\begin{array}{l}-0.365 \\
(-0.27)\end{array}$ & $\begin{array}{c}0.853 \\
(-0.42)\end{array}$ & -2.286 & $\begin{array}{l}12.390 \\
(1.58)\end{array}$ \\
\hline L. Debt & $\begin{array}{c}0.039 * * * \\
(3.91)\end{array}$ & $\begin{array}{c}0.042 * * * \\
(4.22)\end{array}$ & $\begin{array}{c}0.044 * * * \\
(4.39)\end{array}$ & $\begin{array}{c}0.043 * * * \\
(4.31)\end{array}$ & $\begin{array}{c}0.044 * * * \\
(4.42)\end{array}$ & $\begin{array}{c}0.039^{*} \\
(1.87)\end{array}$ & $\begin{array}{c}0.042 * * \\
(2.09)\end{array}$ & $\begin{array}{c}0.044 * * \\
(2.20)\end{array}$ & $\begin{array}{c}0.043 * * \\
(2.15)\end{array}$ & $\begin{array}{c}0.044 * * \\
(2.53)\end{array}$ \\
\hline Unemployment & $\begin{array}{c}-0.604 * * * \\
(-11.15)\end{array}$ & $\begin{array}{c}-0.597 * * * \\
(-11.10) \\
\end{array}$ & $\begin{array}{c}-0.594 * * * \\
(-11.08) \\
\end{array}$ & $\begin{array}{c}-0.576 \text { *** } \\
(-10.62) \\
\end{array}$ & $\begin{array}{c}-0.589 * * * \\
(-11.20)\end{array}$ & $\begin{array}{c}-0.604 * * * \\
(-4.08)\end{array}$ & $\begin{array}{c}-0.597 * * * \\
(-4.09)\end{array}$ & $\begin{array}{c}-0.294 * * * \\
(-4.05)\end{array}$ & $\begin{array}{c}-0.576^{* * *} \\
(-4.10)\end{array}$ & $\begin{array}{c}-0.589 * * * \\
(-4.21)\end{array}$ \\
\hline Inflation & $\begin{array}{l}-0.030 \\
(-1.62) \\
\end{array}$ & $\begin{array}{l}-0.030 \\
(-1.65)\end{array}$ & $\begin{array}{l}-0.029 \\
(-1.57)\end{array}$ & $\begin{array}{l}-0.032^{*} \\
(-1.75) \\
\end{array}$ & $\begin{array}{l}-0.033^{*} \\
(-1.80) \\
\end{array}$ & $\begin{array}{l}-0.030 \\
(-1.28) \\
\end{array}$ & $\begin{array}{l}-0.030 \\
(-1.27) \\
\end{array}$ & $\begin{array}{c}0.029 \\
(-1.27)\end{array}$ & $\begin{array}{l}-0.032 \\
(-1.29) \\
\end{array}$ & $\begin{array}{l}-0.033 \\
(-1.54) \\
\end{array}$ \\
\hline \multicolumn{11}{|c|}{ Finance Ministers' characteristics } \\
\hline Female & & $\begin{array}{c}-1.992 * * * * \\
(-3.21)\end{array}$ & $\begin{array}{c}-1.890 * * * * \\
(-3.05)\end{array}$ & $\begin{array}{c}-2.210^{* * * *} \\
(-3.54)\end{array}$ & $\begin{array}{c}-2.003 * * * \\
(-3.29)\end{array}$ & & $\begin{array}{c}-1.992 * * \\
8-2.31)\end{array}$ & $\begin{array}{c}-1.890 * * \\
(-2.10)\end{array}$ & $\begin{array}{c}-2.210^{* * *} \\
(-2.39)\end{array}$ & $\begin{array}{c}-2.003 * * \\
(-2.35)\end{array}$ \\
\hline Age & & & $\begin{array}{l}0.000 \\
(0.05)\end{array}$ & & & & & $\begin{array}{l}0.000 \\
(0.03)\end{array}$ & & \\
\hline Tenure & & & $\begin{array}{c}0.136^{* * *} \\
(2.47)\end{array}$ & & & & & $\begin{array}{c}0.136^{*} \\
(1.92)\end{array}$ & & \\
\hline Degree 0 & & & & $\begin{array}{c}1.830^{* * *} \\
(2.16)\end{array}$ & & & & & $\begin{array}{l}1.830 \\
(1.48)\end{array}$ & \\
\hline Degree 1 & & & & $\begin{array}{c}1.845^{* *} \\
(2.59)\end{array}$ & & & & & $\begin{array}{l}1.845 \\
(1.53)\end{array}$ & \\
\hline Degree 2 & & & & $\begin{array}{c}1.673^{* * *} \\
(2.23)\end{array}$ & & & & & $\begin{array}{l}1.673 \\
(1.23)\end{array}$ & \\
\hline Degree 3 & & & & $\begin{array}{l}1.292 \\
(1.55)\end{array}$ & & & & & $\begin{array}{l}1.292 \\
(1.13)\end{array}$ & \\
\hline Degree 4 & & & & $\begin{array}{c}2.987 * * * \\
(3.46)\end{array}$ & & & & & $\begin{array}{l}2.987 * \\
(1.98)\end{array}$ & \\
\hline Degree 5 & & & & $\begin{array}{l}1.351 \\
(1.61)\end{array}$ & & & & & $\begin{array}{l}1.351 \\
(1.03)\end{array}$ & \\
\hline \multicolumn{11}{|l|}{ Political developments } \\
\hline Left-wing party & & & & & $\begin{array}{l}0.484 \\
(0.82)\end{array}$ & & & & & $\begin{array}{l}0.484 \\
(0.42)\end{array}$ \\
\hline Right-wing party & & & & & $\begin{array}{l}0.699 \\
(1.17)\end{array}$ & & & & & $\begin{array}{l}0.699 \\
(0.66)\end{array}$ \\
\hline Centre party & & & & & $\begin{array}{l}-1.057 \\
(-1.38)\end{array}$ & & & & & $\begin{array}{l}-1.057 \\
(-0.92)\end{array}$ \\
\hline Majority & & & & & $\begin{array}{l}0.528 \\
(0.31)\end{array}$ & & & & & $\begin{array}{l}0.528 \\
(0.23)\end{array}$ \\
\hline Number seats & & & & & $\begin{array}{c}-0.048 * * * \\
(-5.23)\end{array}$ & & & & & $\begin{array}{c}-0.048^{*} \\
(-1.76)\end{array}$ \\
\hline
\end{tabular}

Note: In Column 1 to 5, the models are estimated by Within Fixed Effects (FE). In Column 6 to 10, the models are estimated by Within Fixed Effects (FE) with robust errors

$\mathrm{t}$ values are reported in parenthesis below each coefficient estimate. ${ }^{*}, * *, * * *$ denote significance at 10,5 and $1 \%$ levels. 